\title{
Socio-Geographical Concept of Labor Market Monitoring and Regional Employment Policy Formation
}

\author{
Kateryna Butkaliuk ${ }^{1}$, Valentyna Shchabelska ${ }^{1}$, Mariia Bykova ${ }^{1}$, and Iuliia Pologovska ${ }^{1}$ \\ ${ }^{1}$ National Pedagogical Dragomanov University, Kyiv, Ukraine
}

\begin{abstract}
The necessity of socio-geographical concept elaboration and implementation for labor market monitoring and regional employment policy formation is grounded from the socio-geographical point of view. It has been established that: 1) the versatility and complex nature of the labor market development specificated by natural and socio-economic factors of important geographical content has determined its socio-geographical essence; 2) the development of the concept requires different approaches, principles and research methods, including socio-geographical, taking into account various labor market factors; 3 ) the concept should take into account the influence of the laws of the production and human settlement territorial organisation, as well as the level of development and structure of the region's economy; 4) the concept should take into account the peculiarities of the labor market formation and development in the economic system agricultural sector as well as the impact of current risks and challenges on the social and labor sphere of public life; 5) the implementation of such a concept has to provide the balancing of labor supply and demand within the country and its regions; 6) regional employment policy should be aimed at rational use of the territory labor potential.
\end{abstract}

\section{Introduction}

In terms of the globalisation processes and the competitive environment development formation, the integration of Ukraine into the world community and membership in the World Trade Organisation (WTO), it becomes necessary to identify the priority areas of economic activity in combination with the effective employment policy formation. In this regard, it is important to establish and develop the concept of labour market. The implementation of such a concept has to provide the balance of labour supply and demand within the country and its regions. This will contribute to the efficient usage of labour resources, promote the employment, provide the adequate wages, stimulate motivation to work and its social prestige. The concept development in the context of complex social transformations requires the new approaches and research methods, with the focus on the geospatial approach. This will provide a holistic picture of the labour market functioning, balance supply and demand, identify the main trends in its development and justify the rational use of labour forces and increase the employment rate.

One of the basic modern principles of the geospatial approach to the labour market formation is the full use of the territory features as a concrete geographical space for the placement of economic activity objects and population. Having a certain capacity for the development and location of production facilities, the territory itself is an independent specific resource that affects the formation of the labour market. This is especially important in Ukraine, when the real distance between objects is significant due to the natural and economic factors. The mutual location and availability of production facilities are important characteristics in determining the interaction conditions of the related industries, the rational use of labour force [11].

\section{Literature review}

The analysis of the publications on this topic shows that except economists, socio-geographers more often analyse a number of issues related to the regional labour markets formation and development. First of all, should be mentioned the O. Levada's thesis, where he made an attempt to consider the labour market from a sociogeographical point of view [8], a number of articles by K. Butkaliuk [1, 2, 3, 4], N. Zapukhlyak [5], I. Melnyk [9], where the attention is focused on the essence of the labour market, factors and features of its formation, analysis of the regional labour market, research methods etc. However, in our opinion, the grounding of the sociogeographical concept of regional labor market development and monitoring, except the disclosing its essence, factors, methods, features, should take into account the impact of production and resettlement territorial organisation. These issues are given relatively little attention in scientific publications. The attempt of defining the influence of the labour territorial division on the regional labour market formation was made by K. Butkaliuk [3]. But researches of complexproportional development of the region's economy, territorial concentration of production and population in 
areas with the most favourable natural and socioeconomic conditions remain out of focus.

The aim of the study is to ground the sociogeographical concept of regional labour market monitoring.

\section{The tasks of the study}

The versatility and complex nature of the labour market development specificated by natural and socio-economic factors of important geographical content has determined its socio-geographical research essence and foundation of socio-geographical concept development and monitoring. Which are as follows:

- identifying the relationship between structural changes in the economy, reforming the social sphere and attracting the labour potential to the economy, taking into account socio-geographical factors and labour market formation global models;

- defining the main concepts, scientific category of the regional labour market as a socio-geographical unit with a rich geographical content;

- forming the methodological approaches to the labour market research, based on the interaction between the economy, social sphere, demographic processes and human labour distribution;

- analysis of the main socio-geographical formation, functioning and development factors, of the labour market, pointing out the structure and specialisation of the region's economy as a necessary condition for its evolution;

- development of the main directions of the regional labour market improvement, increase the employment rate.

\section{The results}

The labour market is a socio-territorial entity which is formed as a result of the interaction of the sphere of employment and the economically active part of the population within a certain region. The basis for the development and, accordingly, labour market monitoring, is the territorial differentiation of production, which is manifested in differences in its structure, specialisation, management forms and territorial concentration. Thus the sphere of labour force application and, accordingly, the demand for labour is being formed. At the same time, the important component of the labour market are the territorial communities of people, especially their economically active part with the necessary physical and spiritual abilities, professional knowledge and specific skills - it is the basis of labour supply. The labour market from this point of view is considered much more broadly than it is interpreted in economics. The study of the interaction between the economically active population and the field of employment is closely related to the analysis of the socio-geographical environment and socio-economic condition of the territory.

The formation of labour markets is significantly influenced by socio-geographical and socio-economic conditions and factors: natural conditions, availability of natural resources, demographic processes, their territorial differences as a basis for labour reproduction, formation of labour potential and professional composition of the population, development of material and technical base and transport communications.

The formation and development of the functional structure of labour potential occurs through the labour market, which is influenced by the territorial and sectoral economy structure. The transformational shifts in the country's economy, sectoral transformations, changes in the ownership structure determine the processes of labour resources reproduction and functioning.

The main indicators of the labour market are as following: the structure of labour resources by type of employment and industry, economic activity of population, balancing the jobs and labour potential in the economy key sectors, demand and employment of labour force, unemployment, underemployment, the workers layoffs by type of economic activity, workload on one workplace, features of the economically inactive population [12].

In 2019 , the share of the working age population was $67.7 \%$ (of which the share of the main working age (25 54 years $)-51.5 \%$, mature working age $(55-64$ years $14.1 \%)$ ), younger than working age $-15.2 \%$, which is $6 \%$ less than in 1991 , and the older age group $-17.1 \%$, which is $4.7 \%$ even more. The total number of working population is declining, which corresponds to the fourth stage of the demographic transition: the population aged 65-69 (2.38 million people) is not replaced by a group of 15-19 years (1.86 million people); and the group of 6064 years (2.83 million people) - a group of 10-14 years (2.22 million people). The total demographic burden per 1,000 people of working age in 2019 amounted to 475 people, including persons aged 0-14 years - 228, 65 years and older -247 .

During the period from 2000 to 2019 , the number of economically active population has decreased by 4.5 million people from 23.1 million to 18.6 million people. This trend is due to the development of negative demographic processes - natural population decline and aging, increasing mortality, entering the working age of a small amount of population that is unable to fully replace those who coming out of the economically active population etc.

According to the statistics of the State Statistics Service of Ukraine, there is a tendency of reducing the demand for labour force, as well as reducing the number of employed people. In 2019, the number of employed citizens of Ukraine aged 15-70 was 16.5 million, which is 4.7 million less than in 2000 and 8.9 million than in 1991. The most negative affects its dynamics had in Ternopil, Kherson and Chernivtsi regions.

The unemployment rate in Ukraine, despite some stabilisation, remains significant and in 2019 amounted $8.2 \%$, which is $0.9 \%$ and $3.4 \%$ less than in 2015 and 2000, respectively. The highest unemployment rate is observed among the age groups $15-24$ years and 15-29 years and is $11.9 \%$. The regions with the highest unemployment rate are 
Donetsk, Luhansk, Poltava, Kirovohrad, Ternopil, Zhytomyr regions, and the lowest - Kyiv, Odessa, Lviv, Kharkiv regions. However, in the regions with the lowest unemployment rates there is a tendency to its increase. In order to strengthen the sustainable integration of the unemployed into the labour market in the medium and long term, it is necessary to develop and implement active strategic measures and programs on the labour market. Such programs can provide temporary employment opportunities and eliminate the shortage of qualified personnel for integration into the labour market in the longer term perspective.

Significant changes also occurred in the structure of employment. During the years of independence, the share of the population employed in the traditional sectors of the economy decreased, while the share of services increased. In 1990 the share of people employed in industry was $-30.7 \%$, agriculture, forestry and fisheries $-17.3 \%$, construction $-9.4 \%$, services $-42.6 \%$ and in $2019-14,8 \%, 18.5 \%, 4.2 \%, 62.8 \%$, respectively. It is clear that there is a growing trend in the number of people employed in the tertiary and quaternary sectors of the economy due to the growing role of business services. This can be clearly seen in the large cities of Ukraine, where the share of those employed in the service sector has reached a similar level in the large cities of Western Europe, which have undergone postindustrial transformations.

In the context of globalisation in Ukraine's economy, as in the most countries of the world, there is a restructuring of employment in accordance with the requirements of the market, which is the cause of new, non-traditional forms. Non-traditional or "non-standard" forms of employment include: part-time employment, employment on fixed-term employment contracts, temporary, non-permanent employment, including borrowed labour, secondary employment, remote employment, employment on the basis of civil employment contracts, non-employment, including selfemployment, unregistered employment in the formal sector. They are distinguished from standard employment by the creativity and flexibility of their work schedule due to the use of scientific and technological progress and computer technology.

Employment in the informal sector of Ukraine's economy is quite common. In 2019, it amounted to 3.5 million people, or $21 \%$ of the total employed population aged 15-70 (according to the ILO methodology). Compared to 2000, this category of employees has increased in 1.2 times. Among the economic activities, the most common informal employment was in agriculture, forestry and fisheries (42\%), wholesale and retail trade, repair of motor vehicles (18\%), and construction (16\%). The most common informal employment is among people aged 40 to 49 [17].

The development of the labour market occurs in certain historical, economic, social and natural conditions. Nowadays in Ukraine, in the context of market environment development the significant changes in the role of factors influencing the development of regional labour markets are happening. The role of macroeconomic conditions, economic-spatial and geopolitical location of the region, investment activity, scientific and technological progress and globalisation processes has significantly increased. It is a matter of wide implementation of world scientific and technical achievements in economy, provide the investment activity and innovation policy that is especially shown in the intellectual labour market formation.

Thus, the modern economy and society, generated by the fourth industrial revolution, are transforming, changing and emerging in a new format. The new economy (it is also digital, and network, and knowledge, and creative, etc.) opens the new opportunities and limitations of material, social, psychological, sociocultural nature for the working person. Many assessments and forecasts state that with the development of a new (digital) economy and other today's realities, the global society should expects a collapse in the field of labour and employment. In particular, the well-known ratio of 20:80, at which economic activity will require no more than $20 \%$ of the economically active population, who can acquire the status of employed. The opposite assessments and forecasts, tell that in the new (digital) economy the mass disappearance of some jobs will be accompanied by the emergence of the new ones that can relieve the tension in the labour market [7].

According to the well-known modern economist R. Sharma, with the further transformation of jobs, people will probably replace the workplaces dedicated to robots and artificial intelligence with the new ones that we can't even imagine yet [16].

Conditions have been formed under which the symbiosis of new technologies, institutions of labour organisation, production and management, the new structure of resources and factors of acquiring undeniable competitive advantages and many other factors radically change all components of the social and labour sphere. [7]. The concept of labour market monitoring should take into account the nature of current phenomena and processes, which produce both the new opportunities and the new constraints and challenges in the field of social and labour development. Nowadays, the intellectual potential of Ukraine and its regions is ranked first among the factors of economy development. It is impossible to gain a significant advantage in today's globalised world only through the latest technologies. The human capital in the form of abilities, skills, professional knowledge is more powerful and promising. Along with purely professional knowledge of the system forming industries, in particular in the fields of agricultural production, food industry, serving industries, it is important to have market-oriented specialists. Investments in human capital can provide a powerful, stable and integrated economic and social effect.

The labour market has to take into account the country level of economic development, its position in the world community, the competitiveness of products, including intellectual, in domestic and world markets. The territorial structure of population production and settlement, the degree of territory urbanisation also play an important role. Regional differences in the labour market development significantly depend on the 
existence of industrialised regions, growth poles, centres that attract labour force, including highly qualified. In particular, from peripheral agricultural regions, where the opportunities for employment are significantly reduced, migration processes are intensifying to the urban systems with the developed industry and tertiary and quaternary service sectors. The labour market is in fact an indicator of socio-economic development of the country or region, the territorial organisation of society, demographic and migration processes, the living conditions of the population in the regions [10]. The formation of regional labour markets is closely linked with the laws of territorial production and settlement organisation of population, the complex-proportional development of the region's economy.

The formation of regional labour markets is based on the territorial division of labour, which determines the spatial differentiation of socially useful labour. Spatial forms of organisation of production and the population interact here through the exchange of goods, including "labour force". The effect of the regularity of the labour force territorial division is manifested in the production specialisation, it is concentrated in certain areas. As a result, certain combinations of productive forces are developing, which act as the core of local or regional economic entities. Respectively develop labour demand and supply, which is the basis of local or regional labour markets [3, p. 268].

Complex-proportional development of the Ukrainian regions is the result of intra-regional specialisation. It is achieved on the basis of coordination between industries, interrelations between the basic, auxiliary and service parts of production, between work application sphere and economically active population. It is one of the main preconditions for optimal labour market creation and maximal public involvement in specific activities. The displaying of regularity of the region complex development concerning the formation of the regional labour market consists in interconnected functioning and the most rational objects arrangement of economic activity and population settlement systems, balanced development of labour potential and spheres of labour application.

Territorial concentration of production and population in areas with the most favourable natural and socio-economic conditions is an important pattern of production territorial organisation, which also significantly affects the formation of the regional labour market. At the same time, the possibilities of production concentration and labour demand growth increase the level of employment. The forms of territorial production concentration such as specialised areas and local entities, on the basis of which regional specialised markets are developed (sugar, grain, fuel and energy, engineering), are emerged. Increasing the production concentration and the level of its territorial concentration, the development of agglomeration in the production and resettlement system, the formation of industrial and territorial complexes, the creation of megacities, technology parks, etc. are caused large-scale transformation in market conditions.
The territorial concentration allows to increase the rate of territory development and to form a complete industrial infrastructure, the most appropriate use the group forms of population resettlement. As the concentration of production increases labour-intensive industries become more dependent on the allocation of labour resources. At the same time, the concentration of production activities and the introduction of innovations lead to increased demands on the labour force, their educational and professional level. For example, in such regions as Dnieper, Donbass and within certain urban agglomerations due to the concentration of production, the supporting centres for the location of productive forces and the territorial organisation of the economy and population resettlement are formed. They perform a system-forming role in the development of regional labour markets. Thus, industrial centres and nodes, which arise on the basis of several small and mediumsized enterprises of the same type or one large and two or three related enterprises, create in these economic regions the zones of attraction for labour force, which gradually increases the impact on nearby settlements and strengthen the labour relations. The effectiveness of the regional labour market development mostly depends on the availability of such centres in each administrative region and level of their formation.

Thus, the supporting centres of productive forces location and territorial organisation of the economy and population settlement in each administrative region became the core of intra-regional labour markets, and their functional development determines the labour markets specialisation. It is important to take into account the hierarchy of the supporting centres, which is represented by four levels (local, district, inter-district and regional centres) in the administrative areas [13]. These centres determine the hierarchy of labour markets in the region. Local centres are the basis for the formation of local labour markets, district centres are the core of the labour markets in administrative districts. Inter-district centres are the basis for the development of inter-district labour markets. The regional centre determines the formation of the labour market of interdistrict importance using of the territory of the adjacent administrative districts.

The development of labour markets and their territorial organisation in Ukraine is significantly influenced by the settlements structure and territorial composition of settlements which outlines the territorial boundaries of the labour market to some extent. During the interaction between production systems and population resettlement, the creation of transport arteries, a spatial compositional axis is formed around which the market process develops. Depending on the specialisation, the level of production concentration, the character of the economic centres location and the development of transport infrastructure, the economic system-forming framework is formed, which affects the capacity, size and market conditions.

The structure of the district's economy has a crucial influence on the regional labour market formation. The development of different types of economic activity, their sectoral distribution, intersectoral formations, 
integration of production and marketing are the basis of market segmentation and the allocation of its types. The economy structure mostly determines the social structure of the economically active population. There is a distribution of employees by areas of employment, taking into account the educational, professional and qualification composition of the working population. Eventually, the structure of the economy affects the level of employment in the region and the formation of reserve labour force.

As for the territorial structure of Ukraine's economy, it has undergone significant changes as a result of the transition to the market economy. Thus, the specialised sugar beet, grain, fruit and vegetable canning areas have lost their positions. It should be noted that currently the territorial labour market of agricultural regions with a high agro-industrial and environmental load on land resources is characterised by an imbalance in labour supply and demand.

The labour market formation is influenced by investment activities. This leads to the emergence of new economic centres, changes in interregional proportions, increasing the area of active economic development [6, p.129], which will positively affect the formation of demand in the regional labour market.

The formation and development of the labour market in the agricultural sector has its own characteristics. On the one hand, labour in agriculture is seasonal. Specialisation, concentration, technical level and structure of agricultural production are different from the industrial one. All this determines the territorial differentiation of agricultural production and employment, differences in conditions and amount of work in this sector. On the other hand, the problem of market development is complicated by the demographic situation in rural areas, unfavourable conditions for the economically active population development, low wealth and rural residents' quality of life.

The integral nature of the regional labour market and at the same time its diversity due to a combination of different elements determine the diversity of research, the use of different approaches involving a large volume of statistical, departmental, reference and cartographic information. The study process does not exclude the possibility of using the certain specific methods, techniques and principles of research.

With the development of a competitive environment, intensified attention is given to the study of special labour markets - industrial, agricultural, social orientation and so on. With the reform of the agricultural sector of the economy, the accession to the World Trade Organization, new aspects of socio-geographical research of the agricultural labour market were appeared. The revival of private land ownership and the creation of conditions for the development of management private forms, in particular in agriculture, a significant reduction the role of collective enterprises, equal functioning of different organisational and legal structures determine the necessity of the territorial differences identification in these processes taking into account regional features, their impact on the formation and development of the agricultural labour market.
Technological re-equipment of agro-industrial production, development of the innovative processes with the banks and foreign investments involvement form the competitive advantages of certain regions, their origin opportunities taking into account the natural resource potential, role in the labour force territorial division, socio-economic factors. Therefore, researches of the impact of these processes on the development of the agricultural labour market are of extreme importance.

The formation and development of the labour market as a socio-production-territorial system are based on the following principles:

objectivity, which means that the regional labour market is the result of the interaction of the employment sphere and the economically active population in the territorial dimension;

- territorial differences in the location of production and population, their territorial differentiation as the main condition of the regional labour markets emergence;

- industrial-territorial relations, accessibility to the place of employment as one of the main criteria for determining the labour market boundaries;

the relationship between the region's economic activity, the peculiarities of population settlement and the functional significance of the territory, which affect the sectoral and territorial distribution between the labour activity spheres, labour market segmentation and hierarchy;

- coordination of the labour markets development with the state administrative-territorial structure, the system of population settlement, taking into account the urbanisation of the territory;

the leading role of urban settlement systems, in particular cities (large, medium, small) in the formation of regional labour markets, as they are centres of concentration of labour, economic, cultural and political life, which act as "cores" of the labour market.

Socio-geographical studies of the labour market should be aimed at solving the problems of Ukraine's productive employment and stimulate the motivation for legal employment, creating conditions for selfemployment and entrepreneurship, targeted for improvement of region's labour resources, human capital reproduction, rural areas social revival, tracking regional differences in labour market development in order to develop an effective regional employment policy. These tasks are reflected in the Law of Ukraine 'On Employment' [14] and determine the main strategic directions of socio-geographical research of the labour market. They include identification of labour market formation patterns; grounded the socio-geographical principles of labour market monitoring creation taking into account tendencies of changes in the structure and territorial organisation of economic activity; study of the functioning mechanism of the regional labour market in the conditions of economy globalisation, integration into the EU and membership in the WTO; identification of the large-scale cooperative economic formations impact on the agricultural labour market; the development of the principles of state regional policy on employment etc. 
Only the implementation of management activities on a program-targeted basis in the field of demography reproduction processes and labour use can provide the projected positive changes in the structure of the region's economy, which will lead to a balanced and less labourintensive and redundant path of economic development. Socio-geographical studies of the economic territorial organisation, resettlement and migration flows are of greatest importance for the development of Ukraine's regional employment policy principles.

Regional employment policy is an organisational legal, economic, social, cultural, educational, environmental and administrative state activity, aimed for the rational use of labour resource potential of the territory. Its purpose is to increase the level of efficiency of labour resource potential in the region (socioterritorial complex) due to the competitive advantages (opportunities) of the territory, innovation and investment activities, reducing the level of labour capacity of economy. Its implementation taking, into account socio-geographical factors, requires the creation of geographic information systems (GIS). It is a system of collecting, accumulating, processing and analysing spatial information on labour supply and demand in order to increase the efficiency of the regional labour market.

In determining the regional employment policy priority trends, social, demographic, industrial and other problems are taken into account. The solution of these problems should contribute to the general socioeconomic prosperity of the regions [15].

In the context of a global pandemic, the measures that were taken by national state institutions of different countries, including Ukraine, to limit the spread of COVID-19 and avoid the large-scale population losses, have at least threefold consequences for economic growth. First of all, it is the shock of the proposal. Legislative and executive authorities and local selfgovernment have suspended economic and business activities in a number of economy sectors, including tourism, catering, transport, sports and entertainment. Secondly, it is the shock of demand. The point is that the incomes of the business entities and, consequently, the households in sectors of the economy whose activities are suspended, banned and restricted have fallen sharply and this process is ongoing. The vast majority of households limit their spending due to declining incomes, deteriorating consumer emotions and an unpredictable future. For a short period of time, private consumption has focused on basic necessities. Demand for other goods has declined sharply, which has a negative impact on all areas of economic activity. Thirdly, it is the shock of international trade. Restrictions on the free movement of goods, people, declining the migration flows, trips have led to disruption of global logistics chains, shortages of intermediate goods from countries that have suffered the greatest losses associated with the COVID-19 pandemic. [7, p. 16] The mentioned above makes significant changes in all components of global and national labour markets, while affecting the demand, supply and price of labour force services.

\section{Conclusions}

The employment, the formation and development of the labour market are the reflection of the interaction between the economy, social sphere, demographic processes and the distribution of human labour and require constant attention. The socio-geographical concept of regional market monitoring is based on the theoretical principals of the socio-geographical nature, principles and factors of labour market formation. They are based on the interaction of the employment sphere and the economically active population in their territorial dimension. Therefore, such research is multifaceted and involves the study of branches of tangible and intangible production as a field of labour application. In particular their territorial differentiation, structure, specialisation, forms of territorial concentration. Simultaneously, it is a study of territorial communities of people, their socially useful activities. This takes into account the population dynamics, the peculiarities of its natural and mechanical movement, gender and age structure, spiritual and physical abilities, level of education, professional knowledge, production skills etc.

It is important to take into account the laws of production and resettlement territorial organisation, as well as the economic system structure, which will develop promising areas of labour market, justify the forecast of the most appropriate combination of territorial communities and concentration of production and other economic activities. In order to increase the level of employment productive and balance the supply and demand in the labour market, it is important to provide their monitoring.

\section{References}

1. K.O. Butkaliuk. Socio-geographical factors of regional labor markets formation. Economic and social geography. 53, 78-83 (Kyiv, 2002).

2. K.O. Butkaliuk. The essence and functions of the regional labor market. Geography and Modernity. 9, 82-88 (Kyiv, 2003).

3. K.O. Butkaliuk. The influence of the labor territorial division on the formation of the regional labor market. Socio-geographical problems of productive forces development of Ukraine. 308 (Kyiv, 2004).

4. K.O. Butkaliuk. The methods of socio-geographical research of the regional labor markets. Scientific notes of Vinnytsia State Pedagogical University named after M. Kotsyubynsky. Series: Geography. 9 (Vinnytsia, 2005).

5. N.I. Zapukhlyak. Socio-geographical features of labor market formation. Economic and social geography. 53, 83-88 (Kyiv, 2002).

6. Yu.D. Kachaev. The influence of investment activity on the region's territorial development. Geography in the information society. 4, 129-131 (Kyiv, 2008).

7. A. Kolot, O. Gerasimenko, K. Yarmolyuk-Kryok. The labour sphere in the conditions of the global socio-economic reality 2020: challenges for 
Ukraine, (2020), http://www.fes.kiev.ua Accessed $25 \mathrm{Feb} 2021$

8. O.M. Levada. Socio-geographical bases of formation and functioning of the countryside regional labor market (on an example of the Zaporozhye area). Thesis abstract. 18 (Odessa, 1999).

9. I.G. Melnyk. The labor market study as the direction of socio-geographical research. Actual problems of economic-geographical science and education development in Ukraine. 45-46 (Kyiv, 2003).

10. V.P. Nagirna, K.O. Butkaliuk. Socio-geographical principles of labor market research as an indicator of the efficiency of the region's economy. Geography in the information society. 2, 114 (Kyiv, 2008).

11. V.P. Nagirna, K.O. Butkaliuk. Cluster approach to the labor market formation and the principles of its improvement (socio-geographical aspect). Geography and Modernity. 21, 53-861 (Kyiv, 2009).

12. L.M. Nemets, Yu.Yu. Silchenko, K.A. Nemets, $\mathrm{K}$.Yu. Segida. Labor potential of the Kharkiv region (socio-geographical aspect). 186 (Kharkiv, 2014)

13. E.I. Pityurenko. Settlement systems and territorial organisation of the national economy, 140 (Kyiv, 1983).

14. Law of Ukraine "On Employment of the Population". Information of the Verkhovna Rada, 24 (243), (2013), https://zakon.rada.gov.ua/laws/show/ 5067-17\#Text Accessed 12 Jan 2021

15. V.S. Vasilchenko. State regulation of employment. 252 (Kyiv, 2005).

16. R. Sharma. Rise and Fall of States. The forces of changes in the post-crisis world. 84 (Moscow, 2018).

17. State Employment Center. Analytical and statistical information (2021), https://www.dcz.gov. ua/analitics/68 Accessed 25 Feb 2021 